\title{
Zygmunt Krzyżanowski w kontekście literatury mniejszej - zarys problematyki badawczej
}

Pawee EANiewski

(Uniwersytet Śląski)

W literaturze początku XX wieku, a więc okresu najintensywniejszego rozwoju modernizmu, narodziły się dyskursy, które w otwarty sposób poszukiwały nowego sposobu opisu rzeczywistości, opierały się na zaprzeczeniu kwestii fundamentalnych dla nowoczesności i - w dłuższej perspektywie - dały początek myśli ponowoczesnej. Okres bezpośrednio poprzedzający pierwszą wojnę światową oraz następujący bezpośrednio po niej przyniósł olbrzymią dziejową traumę, która zachwiała wieloma kategoriami konstytutywnymi dla europejskiej świadomości. To właśnie wtedy Rudolf Pannwitz w pracy Kryzys kultury europejskiej po raz pierwszy użył terminu „postmodernizm”, definiującego porozpadową epokę, zrodzoną w rezultacie fiaska wielkiego modernistycznego projektu ${ }^{\mathrm{I}}$. Niewątpliwie ogół obecnych wówczas agresywnych dyskursów i wzmożona działalność autorytarnych aparatów państwowych w znaczący sposób wpłynęły na kształt całego życia kulturalnego, ze szczególnym uwzględnieniem utworów przedstawicieli mniejszości.

Perspektywa nieustannej konfrontacji mniejszości z dominującym aparatem państwowym oraz wynikająca z niej konieczność przekształceń w poetyce i konstrukcji utworów znalazły szczególne odzwierciedlenie w wykładni twórców schizoanalizy: Gillesa Deleuze’a i Félixa Guattariego. Badacze - skupiając się na twórczości Franza Kafki - opracowali ramy zróżnicowanego nurtu literackiego określonego mianem literatur mniejszych. 
Sama teoria schizoanalizy (fr. schizoanalyse), wyłożona w dylogii Anty-Edyp (L'Anti-CEdipe $)^{2}$, wpisuje się w ramy psychiatrii materialistycznej3. Jako metoda psychiatryczna proponuje alternatywne wobec psychoanalizy badanie, opierające się przede wszystkim na analizie oddziaływania na jednostkę zawieszoną pomiędzy biegunami schizofrenicznym i paranoidalnym edypalnych czynników społecznych oraz badaniu pragnień $\mathrm{i}$ ich wpływu na aspekt produkcyjny. Różnica pomiędzy tymi biegunami, wyrażona w planie filozoficznym jako różnica pomiędzy myślicielem Nietzschem i rewolucjonistą Marksem, doprowadza do wytworzenia wielopoziomowych, zróżnicowanych maszyn operujących w polu społecznym. Te z kolei konfrontują się ze zindywidualizowanymi maszynami pragnącymi. W teorii autorów Tysiac plateau „wszyscy jesteśmy brikolerami; każdy ze swoją małą maszyną"4. Jedynym sposobem na uniezależnienie się od faszyzujących czynników edypalnych (do których należą m.in. rodzina, wiara, przynależność do wspólnot, udział w rynku kapitałowym) jest ich radykalne odrzucenie, a więc wzorowane na działaniu schizofrenika przecięcie struktur edypalnych. W tym punkcie zasadniczo rodzi się większość konceptów charakterystycznych dla schizoanalitycznej wykładni - przede wszystkim konfrontująca się z ruchami terytorializacyjnymi schizoidalna linia ujścia oraz antagonistyczny wobec bieguna przynależności i podporządkowania nomadyzm.

Ważnym czynnikiem w wykładni Deleuze'a i Guattariego jest też interpretacja utworów literackich, które akumulują schizoidalny potencjał. Podstawowym obiektem badań tego typu stała się twórczość Franza Kafki - modelowego reprezentanta mniejszości tworzącej w języku kultury dominującej. W takiej perspektywie działalność twórcza reprezentanta mniejszości przekształca się w polityczną działalność wywrotową, dysponującą unikalną możliwością reprezentowania realnego, kolektywnego głosu. Podczas badania tego zagadnienia - na czele ze zgłębianiem samego zjawiska mniejszościowości - zastosowanie znajdują niemal wszystkie kategorie wykorzystywane w teorii schizoanalizy. Wydaje się również, że niezwykle ważną rolę w analizie tekstów literackich tego typu mogą odegrać inne koncepcje - w tym przede wszystkim genealogia i archeologia Michela Foucaulta, poststrukturalistyczne teorie dyskursu czy dekonstrukcja Jacques'a Derridy.

Twórcy Anty-Edypa już w pierwszych próbach opracowania nurtu zaakcentowali jego wewnętrzny pluralizm (literatury mniejsze zawsze występują w liczbie mnogiej) i konieczność poszukiwania kolejnych przestrzeni konfrontowania się

2 Pierwszy tom w polskim tłumaczeniu: G. Deleuze, F. Guattari, Anty-Edyp. Kapitalizm i schizofrenia, thum. T. Kaszubski, Warszawa 2017, drugi: idem, Tysiac plateau, thum. J. Bednarek, red. J. Bednarek, B. Banasiak, przedm. M. Herer, Warszawa 2015.

3 Szerzej o tym zagadnieniu zob. G. Deleuze, F. Guattari, Anty-Edyp..., s. 27 i nst.

4 Ibidem, s. 5. 
bloku dominującego i minorytarnego. W prezentowanym artykule analizie zostaną poddane niektóre aspekty mniejszościowości utworów Zygmunta Krzyżanowskiego - rosyjskiego pisarza polskiego pochodzenia i jednego z najbardziej interesujących przedstawicieli postsymbolizmu.

\section{KAFKA I KrZYŻANOWSKI: KWESTIA BIOGRAFICZNA}

Pisarzem, którego utwory w najpełniejszej formie reprezentują zespół cech charakterystycznych dla nurtu minorytarnego, jest Franz Kafka (I883-1924): osiadły w Pradze Żyd, posługujący się na co dzień językiem niemieckim, ale doskonale odnajdujący się też w kulturze czeskiej. Dominantą jego utworów stał się aspekt mniejszościowy, wyrażający się nie tylko w warstwie ideologicznej, ale również w konstrukcji i w poetyce dzieł. Konstrukt bycia-mniejszością jest u niego obecny ciągle i na każdym poziomie, podobnie jak obecne są różnorodne, wielopoziomowe dyskursy odnoszące się do dominującego dyskursu państwowego. Co szczególnie ważne z tej perspektywy - nieustannie zachodzi także zróżnicowana dekonstrukcja autorytarnego aparatu, którą inicjuje konfrontacja odbywająca się w przestrzeni społecznej i politycznej.

Niemal w tym samym czasie w oddalonym o I50o kilometrów od Pragi, znajdującym się w granicach Imperium Rosyjskiego Kijowie żył inny pisarz wyraźnie wpisujący się w postulaty sformułowane przez francuskich myślicieli. Zygmunt Krzyżanowski (w Rosji znany jako СигизмунА Аоминикович Кржижановский) urodził się w 1887 roku w rodzinie polskich ziemian - Dominika Krzyżanowskiego i Fabiany Krzyżanowskiej z domu Maciejowskiej. Podobnie jak Kafka studiował prawo i kierunki filologiczne ${ }^{5}$, interesował się filozofią, a wkrótce w pełni poświęcił się działalności artystycznej. Poetyka jego utworów jest zresztą bardzo często porównywana do konstrukcji dzieł Kafki ${ }^{6}$. Tworzył w języku rosyjskim, jednak znakomicie posługiwał się również polszczyzną, co pozwalało mu w okresie radzieckim na sporządzenie przekładów dzieł Juliana Tuwima, Stefana Żeromskiego i Adama Mickiewicza, zestawianie zbiorów poezji polskiej oraz stworzenie monografii Aleksandra Fredry.

5 Franz Kafka przez pewien czas uczestniczył w wykładach z filologii germańskiej, zastanawiał się nawet nad porzuceniem prawa i podjęciem studiów na tym kierunku. Zygmunt Krzyżanowski z kolei studiowal filologię klasyczną oraz języki nowożytne na Uniwersytecie Kijowskim.

6 Е. Евтушенко, Строффь века. Антология русской поэзии, Москва 1999, с. 149.

7 А. Бовшек, Глазами друга. (Материаль к биографии Сигизмунда, Аоминиковича Кржижановского), в: Сигизмунд Кржижановский. Собрание сочинений в шести томах, т. 6, сост. и комм. В. Перекьмутер, Москва-Санкт-Петербург 2013, с. 279. 
Obaj pisarze tworzyli w tym samym okresie historycznym, stykali się z pozornie odmiennymi aparatami państwowymi, jednak w rzeczywistości sposób ich działania był niemal identyczny - opierał się na chęci pełnego podporządkowania jednostek, włączenia ich w tryby kolejnych maszyn sprzężonych z państwową perspektywą. Niezwykle ciekawie prezentuje się mapa dyskursów, które oddziaływały na obu autorów. Pierwsze utwory Kafki pojawiły się u schyłku epoki Franciszka Józefa, niemal zbiegając się z przełomowym dla europejskiej myśli cywilizacyjnej zamachem w Sarajewie i początkiem pierwszej wojny światowej (w I9I3 roku powstało opowiadanie Wyrok, w I9I4 roku m.in. Kolonia karna i Przed prawem, w tym okresie Kafka pracował też nad powieściami Proces i Ameryka, a na I9I5 rok datowana jest Przemiana). Oprócz wielkich dyskursów historycznych, związanych z ugruntowywaniem władzy nad wielonarodowym mocarstwem oraz narastaniem nastrojów wojennych, w sytuacji, w której znalazł się Kafka, bardzo ważną rolę odegrał także dyskurs asymilacyjny, któremu byli poddawani austro-węgierscy Żydzi, oraz przeciwstawny wobec niego narastający dyskurs antysemicki. W pierwszym z nich Żyd jawi się jako idealny obywatel, jednostka pozbawiona indywidualnych cech narodowych, pewna forma czystej karty, na którą można nanieść dowolną inskrypcję. Taki model przedstawiano m.in. w szkołach i opracowaniach akademickich, a sam Kafka, jako doktor nauk prawnych, z pewnością musiał się z nim zetknąc ${ }^{8}$. Te dążenia są zresztą wyraźnie widoczne w jego utworach. W posłowiu do niemieckiego wydania Ameryki Max Brod stwierdza: „We wszystkich trzech powieściach chodzi o włączenie jednostki do wspólnoty ludzkiej”. Co więcej, rodzi to kryzysy innego rodzaju - osadzony w czeskiej rzeczywistości Kafka, a w szerszej perspektywie każdy zniemczony Żyd (w tym czasie zaledwie ıo\% mieszkańców Pragi posługiwało się językiem niemieckim), odbierany był jako zdrajca: „wszystko, co jest żydowskie, traktowane jest jako apriorycznie podejrzane o bliską wspólpracę z wrogą niemczyzną"'o. Bernd Neumann, podkreślając rolę tych dyskursów, stawia pytanie, które moglibyśmy zadać także w kontekście Zygmunta Krzyżanowskiego:

\section{1) Czy być może wystarczy dostrzec w fenomenie Kafki jedynie to, że na mocy swego wyjątkowego położenia, jako zasymilowany, nie- mieckojęzyczny Żyd w Pradze, reagował w sposób bardziej wrażliwy niż wszyscy inni na wszelkie zmiany w społecznych i kulturowych energiach? Czy ów wrażliwy Kafka nie był ,jedynie” intensywniej}

8 B. Neumann, Franz Kafka: Aporie asymilacji. Rekonstrukcja tryptyku powieściowego, tłum. S. Mrożek, Wrocław 2012, s. 39 i nst.

9 F. Kafka, Amerika, Frankfurt am Main 1976, s. 261, cyt. za: B. Neumann, op. cit., s. 24.

10 B. Neumann, op. cit., s. 32. 
zanurzonym w dyskursach swoich czasów - jak można by to też ująć - literackim sejsmografem zbliżających się coraz bardziej, a niosących ze sobą przełom wydarzeń? Czyż nie żył w miejscu, w którym specyficzne współoddziaływanie społecznych energii miało stać się wyraźną sygnaturą antycypacji nadchodzących totalitaryzmów XX wieku? ${ }^{\text {II }}$

Młodszy o cztery lata Krzyżanowski debiutował w igıo roku wierszem Бeampuฯe, jednak faza jego dojrzałej twórczości rozpoczęła się w I9I9 rokư ${ }^{\mathrm{I2}}$, a największe dzieła pisarza powstały w latach 1928-I929, kiedy skończyl pracę nad Powrotem Münchhausena (Возврашение Мюнхгаузена), Wspoтnіепіаті z przysztości (Воспоминания о будущем) і Materiatami do biografii Gorgisa Katafalakiego (Mатериаль к биографии Горгиса Катафалаки). Pisarz poświęcił pracy twórczej jeszcze następną dekadę, wieńcząc ją w 1942 roku szkicem Moskwa w pierwszym roku wojny (Москва в первыии год войны. Физиологические очерки). Ramy czasowe twórczej aktywności Krzyżanowskiego zamykają się więc niemal dokładnie w ramach dwudziestolecia międzywojennego i są wyznaczane przed dwa okrutne, totalne konflikty. Sama kwestia pierwszej wojny światowej pozostała natomiast żywa w jego twórczości i wielokrotnie powracała w utworach lat późniejszych.

Pomiędzy tymi dwoma punktami obecny jest jednak bardzo szeroki przekrój autorytarnych dyskursów: od uniwersalistycznego dyskursu moderny i konserwatywnego dyskursu imperialnego charakterystycznego dla schyłku dynastii Romanowów, przez swego rodzaju dyskursywną rizomę ${ }^{\mathrm{I} 3}$ okresu wielkiej wojny, pogłębioną w okresie dwóch rewolucji, bolszewicką i białą propagandę (Krzyżanowski, mieszkający wówczas w Kijowie, znalazł się w samym środku zmagań o miasto ${ }^{\mathrm{I}}$ ), dyskurs okresu komunizmu wojennego, NEP-u, propagandę reakcyjną, na ugruntowanym dyskursie stalinowskim kończąc.

Wywodzący się z polskiej katolickiej rodziny Krzyżanowski zderzał się więc praktycznie nieustannie z wrogimi, radykalizującymi się dyskursami. Jego pochodzenie miało znaczący wpływ na brak możliwości publikowania utworów i wykluczenie z oficjalnego życia intelektualnego kraju: pisarz, pomimo rad przyjaciół, zdecydował się na przyznanie do szlacheckich korzeni, przez co był represjonowany w czasach

11 Ibidem, s. 22-23.

12 Е. Евтушенко, op. cit., с. 149.

13 Rizoma (łac. rhizoma), dosłownie 'kłącze' - model poznawczy wspólny dla myślicieli postmodernistycznych, poststrukturalistycznych i schizoanalitycznych. W przeciwieństwie do tradycyjnego modelu korzenia, który zachowuje ciąg przyczynowo-skutkowy i chronologię, rizoma wskazuje na rozproszony charakter poznania, w którym każdy element, podobnie do korzenia wiązkowego, rozrasta się i łączy z innymi elementami w trudny do skategoryzowania sposób.

14 Zob. A. Бовшек, op. cit., c. 214 (tu i dalej tłumaczenie autora artykułu). 
Związku Radzieckiego ${ }^{15}$. Wydaje się, że - podobnie jak w przypadku Kafki - właśnie ta niemożliwość pogodzenia się z reprezentującym stosunki sił społecznych socius determinuje specyficzny światopogląd, który znajduje bezpośrednie przełożenie na kwestie artystyczne. Anna Bowszek przedstawia tę fundamentalną kwestię w następujący sposób:

\section{\Swój światopogląd Krzyżanowski wypracowywał w procesie długiej walki z samym sobą. Przeszedł nie tylko przez ból serca, ale także przez jeszcze bardziej dotkliwy ból rozumu: „Myśleć - to różnić się z samym sobą". [...] Dogmatyzm i wszelkie upraszczanie uważał za największe zło dla kultury [...]. Już w młodości zaczęła się u nie- go pojawiać chęć odejścia od kontemplacyjnego rozumienia świata i przejścia do praktycznego postrzegania. Pojawił się wybór między Kantem i Szekspirem i Krzyżanowski zdecydowanie i kardynalnie opowiedział się za Szekspirem: „Kiedy człowiek odkrywa śmieszną stronę poznania prawdy, pozostawia swoją filozoficzną dolę i zwraca się ku sztuce, składa apelację wobec pojęć przed sądem obrazów”'16.}

Analizując te dwie pozycje, można zauważyć wspólną perspektywę i zaproponować parafrazę pytania, które w kontekście Kafki zadaje Neumann: czy Krzyżanowski, jako zasymilowany Polak najpierw w Kijowie, a następnie w Moskwie, nie wykazywał się większą wrażliwością na wszystkie polityczne i społeczne zmiany? Czy nie był takim samym „literackim sejsmografem” reagującym na coraz bardziej agresywną grę dyskursów, a miejsca, w których żył (szczególnie Kijów w okresie wojny domowej, co znakomicie oddaje w Biatej grwardii Michaił Bułhakow), nie stały się szczególnymi punktami sprzyjającymi obserwacji nadciągających totalitaryzmów?

Do głosu dochodzą też podobne aporie asymilacji, niemożność wniknięcia do tkanki socius, w pewnej mierze nawet nieświadomy brak możliwości podporządkowania się jego nakazom. I choć perspektywa prezentowana przez Neumanna skrajnie różni się od schizoanalitycznej koncepcji Deleuze'a i Guattariego, skupiając się nie na dążeniu do dekonstrukcji dominującego nurtu, ale na traumie związanej z brakiem możliwości stania się jego częścią, wydaje się, że pomaga przejść do tego, co właściwie stanowi rdzeń literatury mniejszej jako takiej, a więc relację mniejszości wobec większości i „niemożność niepisania [w języku oficjalnym - P. Ł.], ponieważ świadomość narodowa, niepewna lub pozostająca w stanie opresji, musi koniecznie 
wyrazić się w literaturze" ${ }^{\text {"7 }}$. Na pierwszy plan wysuwa się aspekt deterytorializacji nieustannie odnoszący się do pewnego zastanego terytorializmu. W przypadku Krzyżanowskiego to ujęcie prezentuje się wyjątkowo jeszcze $z$ innego powodu tworzony od setek lat terytorializm rosyjski spotyka się w jego czasach z zupełnie nowym, rewolucyjnym kodowaniem, początkowo noszącym charakter internacjonalny, a następnie przesiąkniętym faszyzującą wizją komunizmu charakterystyczną dla Związku Radzieckiego w okresie stalinowskim. Błędem byłoby więc stwierdzenie, że Krzyżanowski był wyłącznie przedstawicielem mniejszości wobec społeczności rosyjskiej (z którą, swoją drogą, się utożsamiał): aspekt rosyjski jest tu jedynie kategorią pośrednią, poddawaną silnej modyfikacji w celu wytworzenia olbrzymiego, dominującego nurtu radzieckiego. Można zastanawiać się nad tym, w jaki sposób wyglądałaby sytuacja Krzyżanowskiego, gdyby nie doszło do rewolucji ıgI7 roku. Być może wówczas, nadal pozostając pod względem społecznym reprezentantem mniejszości polskiej w państwie rosyjskim, nie tworzyłby dzieł, które tak czytelnie wpisują się w ramy estetyki literatury mniejszej. Utrzymanie status quo z okresu, w którym podejmował pierwsze pisarskie próby, wykluczyłoby wiele dyskursów, które wykazywały się największą agresją i wyrządziły twórcy największą krzywdę, wykluczając go pod względem materialnym, społecznym i - co najważniejsze kulturowym poprzez nałożenie na niego nieoficjalnego zakazu publikacji. Być może to właśnie wielkie rewolucyjne nadkodowanie wyzwoliło uśpione wcześniej aporie asymilacji i przekształciło Krzyżanowskiego z przedstawiciela mniejszości w przedstawiciela podwójnej mniejszości. To ono zmusiło go także do obcowania ze światem polityki, który w rzeczywistości Związku Radzieckiego decydował o kształcie niemal wszystkich zachodzących procesów. Co najgorsze - polityka wkroczyła również do świata kultury, którego autonomię pisarz za wszelką cenę chciał zachować.

Krzyżanowski znaczną część swojej twórczości poświęca relacjom mniejszości i większości oraz kwestiom władzy. Pozycjonuje też samego siebie w tym układzie, podkreślając wyraźnie dystans wobec dominującego nurtu, co znajduje odzwierciedlenie w jego notatkach: „Jako pisarz - z kim jestem: z większością czy z mniejszością? Jeśli liczyć według liczby głów, jestem w mniejszości, ale jeśli brać pod uwagę liczbę myśli, jestem w większości”'88.

To upolitycznienie jest zresztą drugą cechą charakterystyczną literatur mniejszych $^{\text {19 }}$ - nie ogranicza się ono wyłącznie do kwestii ideologicznych, ale ma także

17 G. Deleuze, F. Guattari, Kafka. Ku literaturze mniejszej, tłum. A.Z. Jaksender, K.M. Jaksender, wstęp i red. nauk. C. Rudnicki, Kraków 2016, s. 85.

18 С. Кржижановский, Записньце тетради, в: Сигизмунд Кржижановский. Собрание сочинений в шести moмax, т. 5, сост. и комм. В. Перельмутер, Москва-Санкт-Петербург 2010, с. 356.

19 G. Deleuze, F. Guattari, Kafka..., s. 86. 
wpływ na konstrukcję utworów: uwypukla znaczenie każdego zdarzenia indywidualnego, nadaje mu od razu szeroki kontekst społeczny i ,wikła je w politykę"º Tutaj zarysowuje się też różnica pomiędzy literaturami mniejszymi a „wielkimi literaturami”, w których środowisko społeczne jest jedynie tłem dla rozrastającej się siatki zdarzeń, co w swoich notatkach zauważa sam Kafka:

\To, co w obrębie wielkich literatur rozgrywa się na dołach, tworząc wcale nie niezbędne podziemia gmachu, dzieje się tu w pełnym świetle, to, co tam daje powód do chwilowego zbiegowiska, tu wiedzie do skutków wcale nie błahszych niż powszechny wyrok o życiu i śmierci wszystkich $^{2 \mathrm{I}}$.

Dochodzi do pewnego rodzaju odwrócenia: w punkcie centralnym znajduje się to, co w dominującym ujęciu stanowi margines, każde, nawet pozornie błahe wydarzenie może wiązać się z apokaliptycznymi konsekwencjami. Modyfikacji ulega również sama figura pisarza, który jest nie tylko podmiotem czynności twórczej, ale i podmiotem politycznym, wytwarzającym wartość kolektywną, podejmującym de facto decyzje polityczne. Akt pisania nabiera szczególnej wartości i w oczywisty sposób wpływa na kształt tworzonego dzieła. Zgodnie z postulatem Deleuze’a i Guattariego:

\Pisać niczym pies, który kopie swoją dziurę, szczur, który wydrapuje swoją norę. A wszystko po to, by odnaleźć swój własny niedorozwój, własną gwarę, swój własny Trzeci Świat, swoją pustynię ${ }^{22}$.

W tym miejscu rodzi się „literatura marginalna”, a więc literatura sprzeczna z głównym nurtem i z głównym dyskursem, „praktyka mniejszości od wewnątrz”, która jako jedyna daje możliwość obcowania z materią i faktycznego reprezentowania kolektywnego głosu ${ }^{23}$. Jej sensem jest wydobywanie własnego, unikalnego języka, który dysponuje rewolucyjnym potencjałem. Owa marginalność jest również związana $\mathrm{z}$ usilnym rugowaniem literatury mniejszej z dominującego nurtu życia kulturalnego. To dlatego za życia Kafka, mimo znaczącej roli w środowisku praskich intelektualistów, nie odniósł oczekiwanego sukcesu, a jego opowiadania ukazywały się w ograniczonych nakładach. Dopiero za sprawą Maxa Broda utwory

20 Ibidem, s. 87.

21 Ibidem, s. 89.

22 Ibidem, s. 94.

23 Ibidem, s. 96-97. 
autora Zamku zyskały w latach późniejszych międzynarodową sławę. Sytuacja Krzyżanowskiego przedstawiała się jeszcze gorzej. Pisarz, szanowany w kręgach kijowskich i moskiewskich, doczekał się publikacji zaledwie kilku mniej ważnych tekstów. Wszystkie próby przebicia się do najważniejszych czasopism i wydawnictw kończyły się niepowodzeniem, co doprowadziło Krzyżanowskiego do smutnej konstatacji utrwalonej w jego notatkach: „Przez całe swoje trudne życie byłem literackim niebyciem, uczciwie pracującym na bycie"24. Pomimo olbrzymiego talentu i pracowitości Krzyżanowski nie osiągnął za życia żadnego literackiego sukcesu - jego utwory przetrwały dzięki wysiłkom Anny Bowszek i ukazały się po raz pierwszy w I989 roku. Tragiczny impas przedstawia wypowiedź Aleksandra Fadiejewa podczas debaty nad przyjęciem twórcy Powrotu Münchhausena do Związku Pisarzy Radzieckich:

\ - Cóż to takiego? - zapytał. - Jedna, duża grupa nie to, żeby mówiła o człowieku źle, ale po prostu go nie zna, nie ma pojęcia o jego istnieniu. Skąd jest, kim jest, co zrobił? Nie wiadomo. Za to inni, w mniejszości, wychwalają go, uważają za europejskiego pisarza, który może dodać blasku sowieckiej literaturze ${ }^{25}$.

$\mathrm{Na} \mathrm{tym} \mathrm{niezwykłe} \mathrm{podobieństwa} \mathrm{do} \mathrm{Kafki} \mathrm{się} \mathrm{nie} \mathrm{kończą.} \mathrm{Niemal} \mathrm{identycznie}$ wygląda też ich sytuacja rodzinna. Zarówno Kafka, jak i Krzyżanowski mieli trzy siostry (Kafka jeszcze dwóch braci, którzy umarli w dzieciństwie). W podobny sposób kształtowały się także relacje obu twórców z kobietami: Kafka przez większość życia mieszkał z rodzicami, jego narzeczeństwo z Felice Bauer przez wiele lat opierało się właściwie na wymianie korespondencji, a na zamieszkanie z ostatnią miłością Dorą Diamant zdecydował się na krótko przed śmiercią. Tak samo postąpił Zygmunt Krzyżanowski, który przez długie lata pozostawał w związku z aktorką Anną Bowszek, jednak małe komunalne mieszkanie zdecydował się opuścić dopiero wtedy, kiedy stan jego zdrowia nie pozwalał na samodzielne życie. Być może właśnie ta zależność wpływa na powszechny w twórczości pisarzy, rozrywający trójkąt edypalny motyw kawalera. Obaj twórcy zakończyli życie również w podobny sposób: Kafka nie mógł mówić, nie był już w stanie uczestniczyć w produkcji znaczącego, co przedstawia Derrida w Gtosie i fenomenie, Krzyżanowski z kolei prawdopodobnie w rezultacie udaru stracił możliwość rozróżniania liter i wkrótce umart ${ }^{26}$.

24 В. Н. Топоров, „Минус” - пространство Сигизмунда Кржижановского, в: Сигизмунд Кржижановский. Собрание сочинений в шести томах, т. 6, сост. и комм. В. Перельмутер, Москва-Санкт-Петербург 2013 , c. 424.

25 А. Бовшек, op. cit., с. 287.

26 Więcej na temat śmierci Krzyżanowskiego zob. А. Бовшек, op. cit., c. 280. 


\section{ASPEKT PRZESTRZENNY: NOMADA I MIASTO}

Jednym z głównych aspektów literatury mniejszej jest specyficzny sposób odbioru i konstruowania przestrzeni. Właśnie na tę kwestię zwracają uwagę Deleuze i Guattari w zdaniu otwierającym pracę Kafka. Ku literaturze mniejszej: „Jak wniknąć w dzieło Kafki? To kłącze, jama”" ${ }^{27}$. Ta rizomatyczność nie ogranicza się wyłącznie do sfery idei, ale przede wszystkim jest właściwością przestrzenną. Literatura mniejsza, odwracając porządek charakterystyczny dla „wielkiej” literatury, skupia się na detalach, najmniejszych możliwych jednostkach, w sposób naturalny prezentuje perspektywę uciekającą od szerokich ujęć i wielkich płaszczyzn.

Bohaterowie egzystują w dwóch paradygmatach, które opisują twórcy schizoanalizy: przestrzeni gładkiej (koczowniczej, w której rozwija się maszyna wojenna) i wyżłobionej (osiadłej, ustanowionej przez państwo ${ }^{28}$. Stąd bierze się też niezwykła popularność postaci nomady w prozie Krzyżanowskiego. Typowo koczownicze cechy noszą protagoniści jego najważniejszych utworów: Baron von Münchhausen w Powrocie Münchhausena, Sterer we Wspomnieniach z przysztości oraz tytułowy bohater Materiatów do biografii Gorgisa Katafalakiego. Wszyscy trzej istnieją właściwie wyłącznie w ruchu - nieustannie przemierzają przestrzeń, unikają nawiązywania jakichkolwiek relacji, wypracowują też unikalne sposoby przemieszczania się: Münchhausen ucieka z Londynu na grzbiecie konika szachowego, Katafalaki wędruje po siatce ulic metropolii, chcąc w ten sposób obejść świat dookoła, a Sterer konstruuje maszynę czasu, która umożliwiłaby mu ucieczkę do przeszłości. Co znamienne - wszyscy są kawalerami (kiedy Katafalaki przestaje nim być, znika), co łączy ich z bohaterami dzieł Kafki. Jak podkreślają autorzy Anty-Edypa: „Bez rodziny, bez małżeństwa, kawaler jest tym bardziej społeczny, społecznie-niebezpieczny, społecznie-zdradziecki i kolektywny w samym sobie”29.

Właśnie ów rewolucyjny potencjał jest podstawową charakterystyką nomadów Krzyżanowskiego. $Z$ jednej strony, w aspekcie przestrzennym, dekonstruują oni zastane struktury, zajmują się nieustanną produkcją powierzchni gładkiej, deterytorializują ${ }^{30}$ wszelkie możliwe formy terytorializacji (w tym przejawia się ich kluczowa rola dla realizacji założeń literatury mniejszej, a więc rozrywania ugruntowanych, dominujących układów). $Z$ drugiej strony - chociaż ten aspekt

27 G. Deleuze, F. Guattari, Kafka..., s. 33.

28 Idem, Tysiac plateau, s. 587.

29 Idem, Kafka..., s. 262-263.

30 Deterytorializacja - jedno z kluczowych pojęć schizoanalizy, będące schizoidalnym przeciwieństwem procesów terytorializacyjnych (a więc podporządkowujących i hierarchizujących) charakterystycznych dla faszyzującego edypalnego aparatu. 
także jest warunkowany społecznie - wydają się umykać próbom symbolizacji, czyli procesu, który odpowiada za pierwszą totalizację maszyn pragnących jednostek w schizoanalizie (drugi z tych procesów to podporządkowanie rodzinne, któremu też nie podlegają) ${ }^{3 \mathrm{I}}$. W rezultacie nomadzi odsłaniają „odwrotną stronę struktury", funkcjonują bezpośrednio w Realnym, są uosobieniem nieobecności lub braku, zastępującego wszelkie ugruntowane przekonanie o świecie, na czele z logosem, który już u Heraklita utożsamiany był z rozumnością i prawdą ${ }^{32}$. Ta antynomia jest podkreślona i w opisie dwóch paradygmatów przestrzennych Deleuze'a i Guattariego: „To, co gładkie, stanowi nomos, podczas gdy to, co wyżłobione, zawsze ma logos" 33 .

Szczególną przestrzenią jest miasto, które z jednej strony charakteryzuje się najintensywniejszym strukturyzowaniem, z drugiej jednak jest „siłą żłobiącą, która oddaje czy raczej odtwarza przestrzeń gładką, tak na ziemi, jak i w obrębie innych żywiołów - poza sobą, lecz również w sobie"34. Krzyżanowski jest zafascynowany każdą metropolią. Marzy o zobaczeniu Londynu 35 , w którym osadza akcję wielu utworów, w tym Powrotu Münchbausena i Materiatów do biografii..., jego koczowniczy bohaterowie odwiedzają także Berlin i Paryż. W każdym z tych miast na pierwszy plan - zgodnie z drugą cechą literatury mniejszej wymienianą przez Deleuze’a i Guattariego - wysuwają się elementy mniejszościowe, stojące w opozycji wobec nurtów dominujących. Takie minorytarne, ale kluczowe z ontologicznego punktu widzenia znaczenie zyskują w Powrocie Münchhausena mgły, które zasadniczo stają się głównym elementem organizacji przestrzennej miasta:

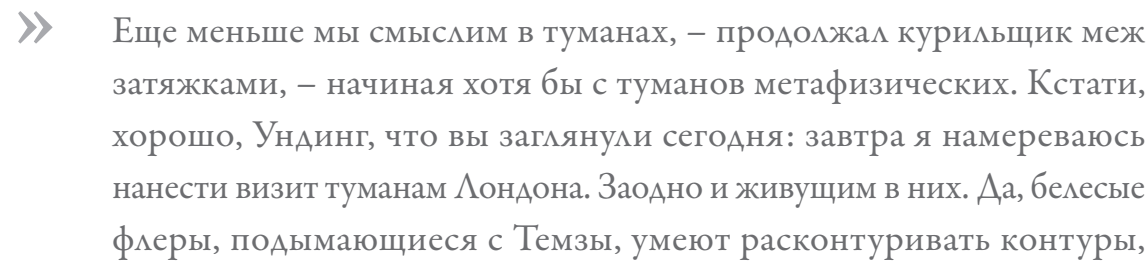

31 Idem, Anty-Edyp..., s. 359.

32 G. Reale, Historia filozofii starożytnej, thum. E. I. Zieliński, t. 1. Od początków do Sokratesa, Lublin 2005, s. 100.

33 G. Deleuze, F. Guattari, Tysiac plateau, s. 591.

34 Ibidem, s. 596.

35 Krzyżanowski wiele czasu poświęcał na naukę języków obcych oraz poznawanie topografii i kultury innych państw. Anna Bowszek opisuje jego fascynację Londynem w następujący sposób: „Pracując nad opowieścią Materiaty do biografii Gorgisa Katafalakiego, długo przesiadywał nad mapą Londynu, skrupulatnie studiował jego ulice, sploty zaułków, skwery, zabytki i zapewne znał je nie gorzej od starych mieszkańców tego zadziwiającego miasta. Opowiadał o tym, że pojedzie ze mną do Anglii, poprowadzi po znajomych ulicach Londynu, pokaże Opactwo Westminsterskie, Trafalgar Square i inne cuda" (А. Бовшек, op. cit., c. 245). 
завуацировать пейзажи и миросозерцания, заштриховать факты и... одним словом, еАу в ОонаОН $^{36}$.

Metropolia skupia w sobie sieć minorytarnych elementów. W paradoksalny sposób rejestr molekularny przeradza się w olbrzymi zestrój molowy. Zafascynowany filozofią Leibniza Krzyżanowski buduje przestrzeń, wykorzystując jego teorię monad. Ta zresztą stanowi podstawę całej ontologicznej wizji sformułowanej przez pisarza. Rzeczywistość składa się z niezależnych monad-atomów natury, mających własne rdzenie i będących samodzielnymi centrami percepcji. Ich układy budują ogół zjawisk, burzą także jakiekolwiek przekonanie o istnieniu jednej, ugruntowanej rozumności i prawdy (logosu):

\Tam zaś, gdzie nie ma części, nie jest możliwa ani rozciągłość, ani kształt, ani podzielność. Monady te są tedy właściwymi atomami natury i jednym słowem pierwiastkami rzeczy. [...] Podobnie jak miasto $z$ różnych stron oglądane wydaje się coraz to inne i stanowi jakby zwielokrotniony perspektywicznie widok, tak dzięki nieskończonej mnogości substancji prostych tyle samo jest jakby rozmaitych wszechświatów, które są wszelako widokami tego samego wszechświata odpowiadającymi rozmaitym punktom widzenia każdej monady ${ }^{37}$.

Każdy element tkanki miejskiej jest więc niejednorodny i ożywiony, reprezentuje samego siebie jako pewnego rodzaju „pierwiastek rzeczy”. Ten schemat jest szczególnie zauważalny w niezwykle skomplikowanych układach metropolii, skupiających w sobie zespól heterogenicznych fenomenów („Восемь тысяч мондонских улиц играли в прятки с его запутывающимися шагами. [...] Маячащие сквозь туман буквы вывесок обещали кофе из Индии, ткани из Персии, замороженное мясо из Китая, фильмы из России, фрукты из Аргентины, фикософию из Германии, парфюмерию из Франции, Ажаз-банА - из Африки" $\left.{ }^{8}\right)$. Krzyżanowski skrupulatnie szkicuje ich rizomatyczną strukturę, na każdym kroku podkreśla brak jednolitości i wynikającą z niego niemożliwość wytyczenia jednej perspektywy, centralnej zasady, która mogłaby sterować życiem wewnątrz tak pojmowanej rzeczywistości.

Pisarz często personifikuje obiekty architektoniczne, skupiające w sobie potencjał semiotyczny danej metropolii. Włącza je do układu ruchowego, za ich

36 С. Кржижановский, Возвращение Мюнхгаузена, в: Сигизмунд Кржижановский. Собрание сочинений в nяти томах, т. 2, сост. и комм. В. Перельмутер, Санкт-Петербург 2000, с. 137.

37 A. Renaut, Era jednostki-przyczynek do historii podmiotowości, thum. D. Leszczyński, Wrocław 2001, s. 44.

38 С. Кржижановский, Материаль к биографии Горгиса Катафалаки, в: Сигизмунд Кржижановский. Собрание сочинений в пяти томах, т. 2, с. 310. 
pośrednictwem doprowadza do rozerwania tkanek, defragmentaryzacji miejskiego układu i finalnego zapanowania nad strukturą. Podobnie jak w przypadku ruchu nomadycznego rezultatem takiego przemieszczenia jest wytyczenie powierzchni gładkiej, powrót do stanu naturalnego, tego, co zgodnie z wykładnią Lacana moglibyśmy określić jako Realne. W ten sposób ożywia londyńską katedrę św. Pawła, która pragnie przejścia do dawnego paradygmatu Szawła, wyrażając tym samym najwyższą formę buntu:

\> Мюнхгаузен уже опустил ногу к ступеньке, как вАруг собор приходит в Авижение, голова его, под гитантско-круглой шапкой, накмоняется, бодая крестом воздух, Авускатная спина выгнулась и чудовище, шевемя всеми своими колокольными языками, кричит: «Сэр, как пройти в Савлы, прямо и не сворачивая?» 39 .

Na taki sam bunt decyduje się też wieża Eiffla w opowiadaniu Zakładka do ksią̇ek (Книжная закладка, 1927). Budowlę wprawia w ruch pragnienie wyzwolone przez rosyjską rewolucję. Kolos niszczy „rozbudzony paniką” Paryż, doprowadza do ucieczki mieszkańców miasta, kroczy w kierunku prowincji i tam również dekonstruuje wszystkie zastane struktury. Powstrzymuje go dopiero połączona siła państw kapitalistycznych (a właściwie, co znamienne, reprezentujących je miast: Nowego Jorku, Berlina, Chicago, Londynu i Rzymu), które do walki z rewolucyjnym zrywem zaprzęgają podległą im maszynę wojenną i doprowadzają wieżę do samobójczej śmierci w wodach Jeziora Bodeńskiego:

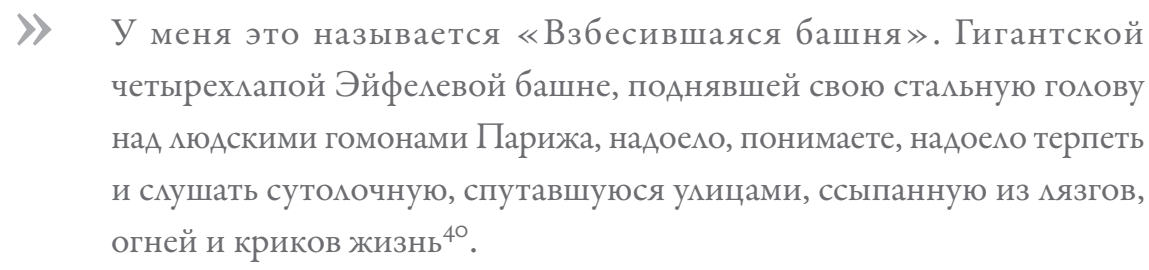

Wyjątkowe miejsce w twórczości pisarza zajmuje Moskwa - miasto, w którym spędził większość swojego życia i które doskonale poznał podczas długich, samotnych spacerów. W stolicy imperium nie interesowały go jednak wielkie układy molowe, ale właśnie perspektywa molekuł. Cykle szkiców poświęca m.in. ulicznym afiszom czy seriom pieczęci. Ważna jest też motywacja wyboru takich ledwie dostrzegalnych obiektów. Krzyżanowski tłumaczy ją w jednym z listów. Okazuje

39 Idem, Возврашение Мюнхгаузен, с. 153.

40 Idет, Книжная закладка, в: Сигизмунд Кржижановский. Собрание сочинений в пяти томах, т. 2, с. 573. 
się, że to właśnie ta mniejszościowa perspektywa „odbicia odbicia” jest mu szczególnie bliska, jako pisarz nie może zajmować się innymi, molowymi tematami. Tym samym przekształca się w analogiczną wobec Deleuzjańskiej maszyny-Kafki - maszynę-Krzyżanowskiego, twór zbudowany z różnych sformalizowanych treści i ekspresji, filtr, przez który swobodnie przechodzą różne fenomeny, wykształcający pewną linię ujścia ${ }^{4 \mathrm{r}}$ :

\> Proszę mi wybaczyć rozczarowanie: przecież pod moją pieczęcią „Moskwa" nie ma niczego oprócz rozważań nad pieczęciami z odciskiem „Moskwa”. Dla mnie ten temat jest bliski i ważny. Dla pana, z perspektywy 700 wiorst, może wydawać się nudny. Ale mogę pisać tylko o tym, o czym mogę: tak wniknąłem do swojego problemu pieczęci, jestem nim tak zajęty, być może zachowuję się jak dziwak podczas studiów nad tym „,szczególnym odciskiem”, który zauważył już Gribojedow, który odróżnia i decyduje o kształcie całego otaczającego mnie życia. Nie mogę i nie umiem wymyślać innych, bardziej zabawnych i ważniejszych dla pana tematów ${ }^{42}$.

W Moskwie znajdują się również wszystkie mikroskopowe przestrzenie mieszkań, w których Krzyżanowski lokuje znaczną część opowiadań. Problem mieszkaniowy, a więc problem w oczywisty sposób polityczny, zyskuje w jego tekstach niezwykle szeroki, ontologiczny kontekst. Brak prywatności i klaustrofobiczne zamknięcie doprowadzają do redukcji osobowości i jej finalnego zaniknięcia. Sam Krzyżanowski większość życia spędził w ciasnych komunałkach, współdzielonych z innymi ludźmi, co niewątpliwie wpływało na pogłębiające się uczucie apatii i rezygnacji. O tym aspekcie życia Krzyżanowskiego i Bowszek wspomina w swoich notatkach krewna pisarza, Nina Molewa: „Sąsiedzi z komunałki w Ziemliedielczeskim zaułku, gdzie mieszkała Anna Gawriłowna, mogli wezwać rewirowego praktycznie za każdym razem, kiedy wujek Zygmunt próbował zostać u niej na noc”43.

Klaustrofobiczna wizja zyskuje najpełniejszy opis w opowiadaniu Kubaturat (Квадратурин, 1926) ${ }^{44}$, w którym bohater o znaczącym nazwisku Sutulin (ros. sututyj 'zgarbiony, skulony') otrzymuje magiczny specyfik pozwalający na powiększenie pokoiku, w którym mieszka (jego rozmiary są tak nikłe, że spacer od ściany

41 G. Deleuze, F. Guattari, Kafka..., s. 55.

42 B. Н. Топоров, op. cit., c. 360.

43 Ibidem, c. 476.

44 Polski przekład autorstwa Walentyny Mikołajczyk-Trzcińskiej znalazł się w zbiorze opowiadań Most przez Styks (red. K. Piwowarski, Warszawa 2008). 
do ściany właściwie sprowadza się wyłącznie do przemieszczenia z pięt na palce). Sutulin jest nieustannie represjonowany przez rozproszony aparat władzy reprezentowany przez wszystkie włączone w jego ramy podmioty: niezliczone rzesze dozorców, sprzątaczek, działaczy i agitatorów. W końcu mieszkanie rozrasta się do niepojętych rozmiarów, a sam Sutulin, przytłoczony poczuciem winy związanym z oszukaniem socius, wydając ostatni krzyk, znika.

\section{DźwIĘK}

Jednym z wyróżników literatury mniejszej jest niezwykłe podejście do kwestii dźwięku i dźwiękowości. To właśnie on inicjuje zdarzenia, lokuje w przestrzeni, towarzyszy temu, co twórcy Anty-Edypa określają mianem „stawania-się-dzieckiem” czy „stawania-się-zwierzęciem”, a więc charakterystycznego dla literatur mniejszych przyswajania cech obiektów minorytarnych ${ }^{45}$. Deleuze i Guattari, powołując się na koncepcję Pierre’a Bouleza, utożsamiają kategorię dźwięku z istnieniem metrum, to jest rytmicznego odliczania pozwalającego na przeniknięcie do przestrzeni żłobionej (odpowiadającej logosowi), wejście w paradygmat foniczny pozwala wobec tego na dostrzeżenie układu elementów. Tej wizji przeciwstawia się natomiast gama dźwięków prostych, które należałoby uznać za naturalne odgłosy charakterystyczne dla perspektywy minorytarnej, pozbawione jakiegokolwiek aspektu strukturyzującego (reprezentujące antystrukturalny nomos) ${ }^{46}$.

W układach tworzonych przez Krzyżanowskiego decydującego znaczenia nabiera interwał, czyli odległość pomiędzy dwoma dźwiękami ${ }^{47}$ - to on jest podstawowym narzędziem strukturyzującym, wyznaczającym granice i dokonującym żłobień. We wspomnianym Kubaturacie dźwięk otwiera i zamyka akcję opowiadania, panuje także nad jego specyficznym rytmem: na początku Sutulin słyszy stukanie do drzwi, następnie uważnie nasłuchuje całego zespołu dźwięków dobiegających $\mathrm{z}$ innych mieszkań i korytarzy, w końcu sam wydaje finalny dźwięk - jego krzyk rozrywa przestrzeń $\mathrm{i}$ towarzyszy transgresyjnemu zniknięciu.

Przestrzeń niemal wszystkich utworów składa się z minorytarnych gwizdów i krzyków. Nieustannie rytm wybija tętent końskich kopyt i stukot kół pociągów. To właśnie dzięki mikroośrodkom czytelnik dowiaduje się m.in. o buncie w Kronsztadzie czy wybuchu pierwszej wojny światowej, o których donoszą mali sprzedawcy gazet. Niezwykłego znaczenia nabiera również dźwięk podstawowe-

45 G. Deleuze, F. Guattari, Kafka..., s. 43.

46 Idem, Tysiac plateau, s. 591.

47 Ibidem, s. 592. 
go atrybutu koczownika - kroków, który de facto pozwala zaistnieć myśli: „ТогАa, вслушиваясь в ритм своих шагов, он привычным психическим усилием завращал в себе ассонансы и ритмы, внешний мир Аля него стал короче помей его фетра - и немая клавиатура слов зашевелила своими клавишами” ${ }^{8}$. Taki dźwięk to „nieukształtowana materia ekspresji”, czysta intensywność, „zawsze nie-znacząca”49, a więc rozrywająca - podobnie jak figura koczownika - cały rejestr symboliczny. Dźwięki pochodzące z ośrodków mniejszościowych mają za zadanie tworzenie przestrzeni gładkiej i wydobywanie linii ujścia. Przeciwstawia im się jednak cała gama dźwięków państwowych, które tworzą te strukturyzowania. Są to wszystkie wystrzały, zwiastujące nadejście represji gwizdki policjantów, pieśni patriotyczne i wojskowe, które agresywnie wkraczają do nomadycznego rejestru i próbują zaburzyć determinujący go czysty ruch.

Niezwykła strukturalna rola dźwięku staje się dominantą cyklu opowiadań Krzyżanowskiego. Sam pisarz zawdzięczał świetne muzyczne przygotowanie matce, która często grywała na fortepianie utwory Roberta Schumanna, Ludwika von Beethovena, Franciszka Schuberta i Fryderyka Chopina. Podobno dysponował także niezwykłym barytonowym głosem, ale zrezygnował $\mathrm{z}$ kariery śpiewaka operowego dla literatury ${ }^{5}$. Muzyka i świat muzyków, zaraz obok rzeczywistości teatralnej, pozostały jednym z głównych zainteresowań pisarza.

Istnieje pewna zależność pomiędzy stopniem ustrukturyzowania dźwięku, a jego wpływem na jednostkę. Dźwięki proste, pomagające oswoić przestrzeń i nadać jej rytm, są czym innym niż rozbudowane utwory, które siłą rzeczy stanowią strukturę samą $\mathrm{w}$ sobie. Ta $\mathrm{z}$ kolei zawsze wiąże się z ryzykiem podporządkowania, zatarcia podmiotowości i finalnej dekonstrukcji osobowości. Proces ten w niezwykle czytelny sposób oddaje opowiadanie Uciekające palce (Сбежавщие nальцьь 1922) $)^{5 \mathrm{I}}$, w którym palce pianisty Dorna postanawiają umknąć podczas uroczystego koncertu. Mniejszościowy element, niesiony chęcią oswobodzenia się od ograniczających go pasaży i akordów, wybiega z sali koncertowej i spędza noc na ulicy, gdzie spotyka się z innymi atrybutami charakterystycznymi dla układów molekularnych. W końcu palce, okaleczone i schwytane przez ,inne palce”, powracają do swojego właściciela, jednak nie są już w stanie z taką samą gracją poruszać się po wytyczonych skalach.

Inicjowana przez dźwięk redukcja zarysowuje się również w opowiadaniu Sonata „Death's Door" (Сoнama „Death's Door” 1939). Bogacz - Mr. Parsnip, po usłyszeniu

48 С. Кржижановский, Возвращение Мюнхгаузена, с. 147.

49 G. Deleuze, F. Guattari, Kafka..., s. 46.

50 А. Бовшек, op. cit., с. 210.

51 Polski przekład autorstwa Hanny Karpińskiej znalazł się w przytaczanym wcześniej zbiorze Most przez Styks. 
dźwięków sonaty, zapada na szybko postępującą chorobę i wkrótce umiera. Ale przed śmiercią, motywowany miłością do młodej i atrakcyjnej żony, nawiązuje kontakt $\mathrm{z}$ hinduskim magikiem, który umożliwia mu zachowanie szczątkowej formy życia i przeniknięcie do materiału jedwabnej kołdry. Wkrótce okazuje się, że kobieta nigdy go nie kochała i zaraz po pogrzebie po raz drugi wyszła za mąż. Parsnip, w akcentowanej „absolutnej ciszy domu”, która konfrontuje się z obecną na samym początku melodią i strukturyzującym ruchem batuty, dusi jej męża i zgodnie ze schizoanalityczną logiką, warunkującą dwustopniowość każdego aktu, odchodzi po raz drugi, tym razem w sposób definitywny.

Krzyżanowski wykorzystuje podobne brzmienie słów Death’s Door (ang. 'próg [właśc. drzwi, wrota] śmierci’) i określenie tonacji Des-dur. Taki zabieg zwraca uwagę na paradoksalność konstrukcji monadycznego świata, bazującego na grze odwrotności. Gama durowa w ujęciu Deleuze’a jest jedną ze struktur, które mogą kształtować wewnętrzne oblicze monad. „Akordy majorowe” (durowe) są w nich „akordami doskonałymi” - tymi, w których „najdrobniejsze niepokojące pokusy, miast zniknąć, łączą się z ciągłą przyjemnością, dającą się przedłużać, odnawiać, mnożyć, rozprzestrzeniać, odbijać, przyciągać innym akordom, nam zaś dają siłę nieustannie podążać gdzieś dalej" ${ }^{2}$. To one odpowiadają za dynamizację układu, umożliwiają pewnego rodzaju przejście do innych wartości, uruchamianie kolejnych podzespołów, kojarzone są z epifanicznym stanem „szczęścia”. Po przeciwległej stronie plasują się „akordy minorowe” (mollowe), które mają możliwość zaistnienia, gdy „stosunki różniczkowe między nieskończenie małymi wielkościami pozwalają jedynie na nietrwałe scałościowanie i zestawienia, proste przyjemności, obracające się w swe przeciwieństwo, o ile nie zostaną pociągnięte przez jakiś akord doskonały”53. Przeciwieństwa skal muzycznych w idealny sposób obrazują „odwrotności”, które skupiają w sobie same monady. Wykorzystana w utworze Krzyżanowskiego gama Des-dur ma równoległą skalę molową b-moll, w której Chopin skomponował m.in. II Sonate fortepianowa (jej III część, Marche funèbre: Lento, to słynny marsz żałobny). Trzecim możliwym elementem są „akordy dysonansowe”, w których „zgodność zawiera się w przygotowaniu i rozwiązaniu dysonansu, jak w dwojakim działaniu muzyki barokowej”54. Ten dysonans, składający się z „pół-cierpień towarzyszących przyjemności” jest pewnego rodzaju wyprzedzeniem możliwego cierpienia, jednostką umożliwiającą „rozwiązanie” go przez znalezienie majorowej linii ujścia 55 .W szerszym ujęciu ten harmoniczny schemat wpisuje się w całą Leib-

52 G. Deleuze, Fatda. Leibniz a barok, tłum. M. Janik, S. Królak, Warszawa 2014, s. 303.

53 Ibidem, s. 304.

54 Ibidem.

55 Ibidem. 
nizjańską ontologię zła, opartą na usuwaniu dysonansów z powszechnej harmonii. Podobną rolę odgrywa w monadycznej koncepcji Krzyżanowskiego, w której sam dysonans staje się motorem napędowym kolejnych wydarzeń, czynnikiem dekonstruującym opozycje, wskazującym zarówno na ekstatyczne aspekty majorowe, jak i na nieustannie obecne akordy minorowe.

\section{Podsumowanie}

Omówione aspekty twórczości Krzyżanowskiego stanowią zaledwie zarys badań nad obecnymi w niej konstruktami mniejszościowymi. Ta perspektywa - wraz z korespondującą z nią schizoanalityczną wykładnią - umożliwia wydzielenie i usystematyzowanie zdecydowanie większej liczby podobnych kategorii, które zasługują na oddzielny i wyczerpujący opis. Jedną z najważniejszych z nich jest szczególna forma nomadyzmu, rozwijana przez pisarza w jego najważniejszych opowieściach (zauważalna zwłaszcza w Powrocie Münchbausena, Wspomnieniach z przyszłości oraz Przyczynku do biografii Gorgisa Katafalakiego, ale kluczowa również dla właściwego odbioru cyklu Bajki dla Wunderkindów). Bez wątpienia minorytarne cechy nosi także filozofia fantomu, pod wieloma względami tożsama nie tylko $z$ naczelną ideą literatur mniejszych, a więc $z$ immanentnym odrzuceniem molekularnego świata wielkich wartości, ale też z widmontologią Jacques'a Derridy i filozofią indywidualizmu Maxa Stirnera.

Bardzo ważną rolę odgrywa również warstwa językowa, czyli, w ujęciu minorytarnym, sposób, w jaki przedstawiciel mniejszości przekształca tkankę języka dominującego. Literacka wizja Krzyżanowskiego i pod tym względem odpowiada obrazowi literatury mniejszej, który wyłania się z prac Deleuze’a i Guattariego: według Lilii Promach pisarz stworzył 948 nowych form, w tym 628 neoleksemów ${ }^{56}$. Szczególną cechą jego poetyki jest także niezwykle częste wykorzystywanie synekdoch i przekształcenia najbardziej terytorializujących (a jednocześnie minorytarnych ze względu na społeczne ulokowanie) jednostek, za jakie należy uznać przysłowia i porzekadła.

Wszystkie te zabiegi wpisują się w szerszym ujęciu w postulaty teoretyków poststrukturalizmu i bez wątpienia świadczą o przełomowym charakterze twórczości pisarza. Przede wszystkim na uwagę zasługuje pluralizm konstruowanej w ten

56 А. В. Промах, Словообразовательнье особенности лексических новообразований С.А. Кржижановского, Аиссертация на соискание ученой степени кандидата филологических наук, Научный руководитель: Аоктор филологических наук, профессор Т. В. Попова, Уральский Федеральный Университет имени первого президента России Б. Н. Ельцина, с. 223-238. Dostęp online: http://elar.urfu.ru/bitstream/10995/54229/1/urfu1757_d.pdf(stan z 1 lutego 2019 r.). 
sposób perspektywy i podporządkowanie jej konstytutywnej dla ponowoczesnego dyskursu kategorii pustki związanej z zanikiem centrum i wypracowaniem specyficznego podejścia do obcowania $\mathrm{z}$ „Innym”.

\section{BiBLIOGRAFIA:}

Bowszek A., Gtazami druga. (Matieriaty k biografii Sigizmunda Dominikowicza Krżyżanowskogo), w: Sigizmund. Krżyżanowskij. Sobranije soczinienij w szesti tomach, t. 6, sost. i komm. W. Perlmuter, Moskwa-Sankt Petersburg 2013;

Deleuze G., Fatda. Leibniz a barok, tłum. M. Janik, S. Królak, Warszawa 2014;

Deleuze G., Guattari F., Anty-Edyp. Kapitalizm i schizofrenia, tłum. T. Kaszubski, Warszawa 2017;

Kafka. Ku literaturze mniejszej, tłum. A.Z. Jaksender, K. M. Jaksender, wstęp i red. nauk. C. Rudnicki, Kraków 2016;

Tysiac plateau, tłum. J. Bednarek, red. J. Bednarek, B. Banasiak, przedm. M. Herer, Warszawa 2015; Jewtuszenko J., Strofy wieka. Antotogija russkoj poezii, Moskwa 1999;

Krżyżanowskij S., Wozwraszczenije Miunchgauziena, w: Sigizmund Krżyżanowskij. Sobranije soczinienij w piati tomach, t. 2, sost. i komm. W. Perlmuter, Sankt Petersburg 2000;

Zapisnyje tietradi, w: Sigizmund. Krżyzanowskij. Sobranije soczinienij w szesti tomach, t. 5, sost. i komm. W. Perlmuter, Moskwa-Sankt Petersburg 2010;

Kniżnaja zagadka, w: Sigizmund Krżyżanowskij. Sobranije soczinienij w piati tomach, t. 2, sost. i komm. W. Perlmuter, Sankt Petersburg 2000;

Krżyżanowskij S., Matieriaty k biografii Gorgisa Katafalaki, w: Sigizmund Krżyżanowskij. Sobranije soczinienij w piati tomach, t. 2, sost. i komm. W. Perlmuter, Sankt Petersburg 2000;

Neumann B., Franz Kafka: Aporie asymilacji. Rekonstrukcja tryptyku powieściowego, tłum. S. Mrożek, Wrocław 2012;

Promach L., Stowoobrazowatielnyje osobiennosti leksiczeskich nowoobrazowanij S.D. Krżyżanowskogo, dissiertacija na soiskanije uczenoj stiepieni kandidata fiłołogiczeskich nauk, naucznyj rukowoditiel: doktor fiłołogiczeskich nauk, profiessor T. W. Popowa, Uralskij Fiedieralnyj Uniwiersitet imieni pierwogo prezidenta Rossii B.N. Jelcyna;

Reale G., Historia filozofii starożytnej, tłum. E. I. Zieliński, t. 1. Od początków do Sokratesa, Lublin 2005;

Renaut A., Era jednostki - przyczynek do historii podmiotowości, tłum. D. Leszczyński, Wrocław 2001;

Sidorina T. J., Fitosofija krizisa. Uczebnoje podsobije, Moskwa 2003;

Toporow W. N., „Minus”-prostranstwo Sigizmunda Krżyżanowskogo, w: Sigizmund Krżyżanowskij. Sobranije soczinienij w szesti tomach, t. 6, sost. i komm. W. Perlmuter, Moskwa-Sankt Petersburg 2013.

SŁOWA KLucze: Krzyżanowski, literatura mniejsza, schizoanaliza, postsymbolizm 


\section{ПАВЕ $\Lambda$ АНЕВСКИЙ}

\section{СИГИЗМУНА КРЖИЖАНОВСКИЙ В КОНТЕКСТЕ МААЫХ АИТЕРАТУР: ВВЕАЕ- НИЕ В ПРОБАЕМАТИКУ}

Понятие малых митератур, сформулированное Жилем Аелезом и Феликсом Гваттари, занимает особенное место в современном митературоведении. Социацьная специфика авторской позиции предопределяет широкий спектр вариантов модификаций языка, поэтики и композиции, а также отвечает за формирование уникального фимософского фона, приспособленного Аля высказывания меньшин-

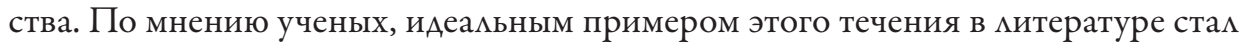
Франц Кафка - пражский еврей, писавший на немецком языке. Автор статьи очерчивает проблематику исследований темы меньшинства в творчестве Сигизмунда Кржижановского - русского писателя польского происхождения, одного из самых интересных преАставителей постсимволизма, наследие которого по политическим причинам известно стало только во время перестройки. Рассматриваемые вопросы (общественная позиция Кржижановского, стратегия конструирования описаний пространства, роль звука в его художественном мире) явцяются вступлением к дальнейшим исследованием поэтики малой митературы и философских концепций в прозе писатемя.

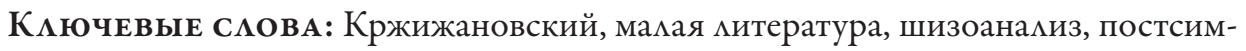
волизм

\section{Pawę Eaniewski}

ZYGMUNT KRZYŻANOWSKI IN THE CONTEXT OF MINOR LITERATURE - AN OUTLINE OF RESEARCH TOPICS

The trend of minor literatures, defined by Gilles Deleuze and Félix Guattari, took up a special place in contemporary literary research. The particular social status of the creator determines within them a wide range of modifications to the fabrics of language, poetics and composition. It is also responsible for the development of a unique philosophical background, adapted to representing the voice of the minority. From the researchers' point of view, Franz Kafka became the model writer of this movement: a Jew from Prague, writing in German. The author of the article presents an outline of research into the aspects of minor-ness in the work of Zygmunt Krzyżanowski - a Russian writer with a Polish background, one of the 
IO4

most interesting representatives of post-symbolism, whose writings, for political reasons, were only discovered at the time of the perestroika. The issues discussed (Krzyżanowski's social status, his strategy of constructing descriptions of space, the role of sound in his artistic vision) constitute an introduction to further studies on minority poetics and philosophical concepts present in his prose.

KeYwords: Krzyżanowski, minor literature, schizoanalysis, post-symbolism 